\title{
Species-Dependent Effects of Border Cell and Root Tip Exudates on Nematode Behavior
}

\author{
Xiaowen Zhao, Mark Schmitt, and Martha C. Hawes
}

Department of Plant Pathology, 204 Forbes Building, University of Arizona, Tucson 85721. Accepted for publication 7 August 2000.

\begin{abstract}
Zhao, X., Schmitt, M., and Hawes, M. C. 2000. Species-dependent effects of border cell and root tip exudates on nematode behavior. Phytopathology 90:1239-1245.

Effects of border cell and root tip exudates on root knot nematode (Meloidogyne incognita) behavior were examined. In whole-plant assays using pea, $M$. incognita second-stage juveniles (J2) accumulated rapidly around the 1- to 2-mm apical region ensheathed by border cells, but not in the region of elongation. Within 15 to $30 \mathrm{~min}$, J2 which had accumulated within detached clumps of border cells lost motility and entered into a quiescent state. When border cells (and associated root tip exudates) were washed from pea roots prior to challenge with nematodes, no such accumulation and quiescence was induced. Attraction of nematodes by roots was species dependent: no attraction or accumulation occurred in snap bean. Using a quantitative assay, three categories of chemotaxis

responses occurred: attraction (pea and alfalfa cv. Thor), repulsion (alfalfa cv. Moapa 69), and no response (snap bean and alfalfa cv. Lahonton). In contrast, total root tip exudates from all three plant species acted as a repellent for $M$. incognita in the sand assay. An in vitro assay was developed to characterize the induced quiescence response. When total root tip exudate from the tested legumes (as well as corn) was incubated with $\mathrm{J} 2$ populations, $>80 \%$ of the nematodes lost motility. A similar response occurred in Caenorhabditis elegans. Border cell exudates did not induce or contribute to the induction of quiescence. Cocultivation of pea border cells with $M$. incognita resulted in changes in border cell shape similar to those observed in response to exogenous plant hormones. No such changes occurred in snap bean border cells. Understanding the cell- and host-specific extracellular recognition that occurs between roots and pathogenic nematodes in the early stages before infection occurs could lead to new avenues for disease control.
\end{abstract}

Plant parasitic nematodes cause crop losses of from 5 to $12 \%$ annually, and the banning of pesticides effective against these pathogens increasingly has restricted control methods (31). Therefore, the need for research into new methods to prevent nematode infection has been emphasized in recent years (36). Most nematode infection is thought to occur by passive dispersal, moving along with the root tip as it grows (30). Like most root-associated pathogens, infection by nematodes such as Meloidogyne incognita is initiated in newly generated elongating tissue several millimeters behind the root apex, and does not occur in mature tissues $(5,7)$. Functionally, this means that infection within any given region of elongation must occur within 1 to 2 days after the cells are generated by cell division. Therefore, interfering in the process of infection during this limited developmental window offers opportunities to inhibit infection before it begins. An awareness of such possibilities inspired early studies to identify attractants or repellents that might prevent initial contact between infective nematodes and susceptible young root tissue $(1,23,24,26,32,33)$.

Initial recognition of the host by nematodes involves signals from roots that stimulate egg hatch, attraction toward roots, and specific attraction to target tissues $(7,26,30)$. The identification and manipulation of any plant chemical needed in any of these stages of nematode-host recognition potentially could be utilized to control infection. Early studies designed to explore such an approach met with a biological complexity that thwarted simplistic applications, such as identifying a chemical that could be added to soil to inhibit movement of nematodes toward host plants, or to stimulate movement toward nonhost plants. Several researchers reported that exudates from a single root could attract,

Corresponding author: M. C. Hawes; E-mail address: mhawes@u.arizona.edu

Publication no. P-2000-0907-01R

(c) 2000 The American Phytopathological Society repel, or be neutral in their ability to influence nematode behavior and suggested that the actual behavioral response was determined by the particular combination of signals at a given time or place $(11,12,33,34)$. Subsequent studies have largely confirmed this early speculation, but few detailed studies have been undertaken. The goal of using root exudates to manipulate initial root-nematode recognition failed to materialize because of experimental limitations (2). Methods to identify cellular sources of biologically active root exudates, to determine how each component might influence the outcome, and to manipulate the production and export of such materials from plants were not available. As a result, few additional studies were carried out and very little information is available about how signals from roots specifically influence nematode behavior (7).

The primary focus of research in our laboratory is the characterization of cell-specific gene expression leading to the production and export of water-soluble root exudates, including proteins, carbohydrates, and secondary metabolites (3,16-19). Most root exudates in young, healthy plants come from the root tip region (here defined as the terminal 1 to $2 \mathrm{~mm}$ at the root apex) and consist of root border cells and their associated extracellular materials $(10,16,25)$. Secretions from the root cap per se include enzymes, antibiotics, and other soluble molecules in addition to a high molecular weight mucilage that encases border cells. Border cells per se provide the bulk of the weight of the exudates, and these specialized cells also actively secrete an array of proteins and other extracellular products. Finally, cell wall breakdown products are released as thousands of root cap cells differentiate into border cells. In legumes, this material released from root tips provides up to $98 \%$ of the total root exudates (10). Recent progress has led to the development of methods to separate cellular sources of root exudates, and to the development of transgenic plants with specific alterations in the expression of genes needed for the production of root exudates $(3,4,35,37)$. Such tools offer an opportunity to reexamine root exudation and its role in nematode infection. 
In this study, the impact of legume root exudates on nematode behavior was characterized. The results revealed that different sources of root exudates dramatically affect nematode behaviors, including chemotaxis and motility. The effects of border cell exudates are distinct from the effects of root tip exudates (defined here as all material remaining after border cells have been pelleted to separate them from the mixture) and vary according to plant cultivar. In addition, extracellular chemicals from $M$. incognita, but not Caenorhabditis elegans, induce morphological changes in border cells.

\section{MATERIALS AND METHODS}

Plant material. Test species, all of which are hosts for $M$. incognita infection $(6,14)$, included pea (Pisum sativum, cv. Little Marvel; Chesmore Seeds Co. St. Joseph, MO), alfalfa (Medicago sativa L., cv. Thor V6086; Northrup King Co. Orivada, NV), snap bean (Phaseolus vulgaris, cv. Romano pole; Bakker Brothers Inc. Twin Falls, ID), and corn (Zea mays, cv. B73 ${ }^{+}$, a gift from B. Larkins, Department of Plant Sciences, University of Arizona, Tucson). Differentially susceptible alfalfa cultivars which are
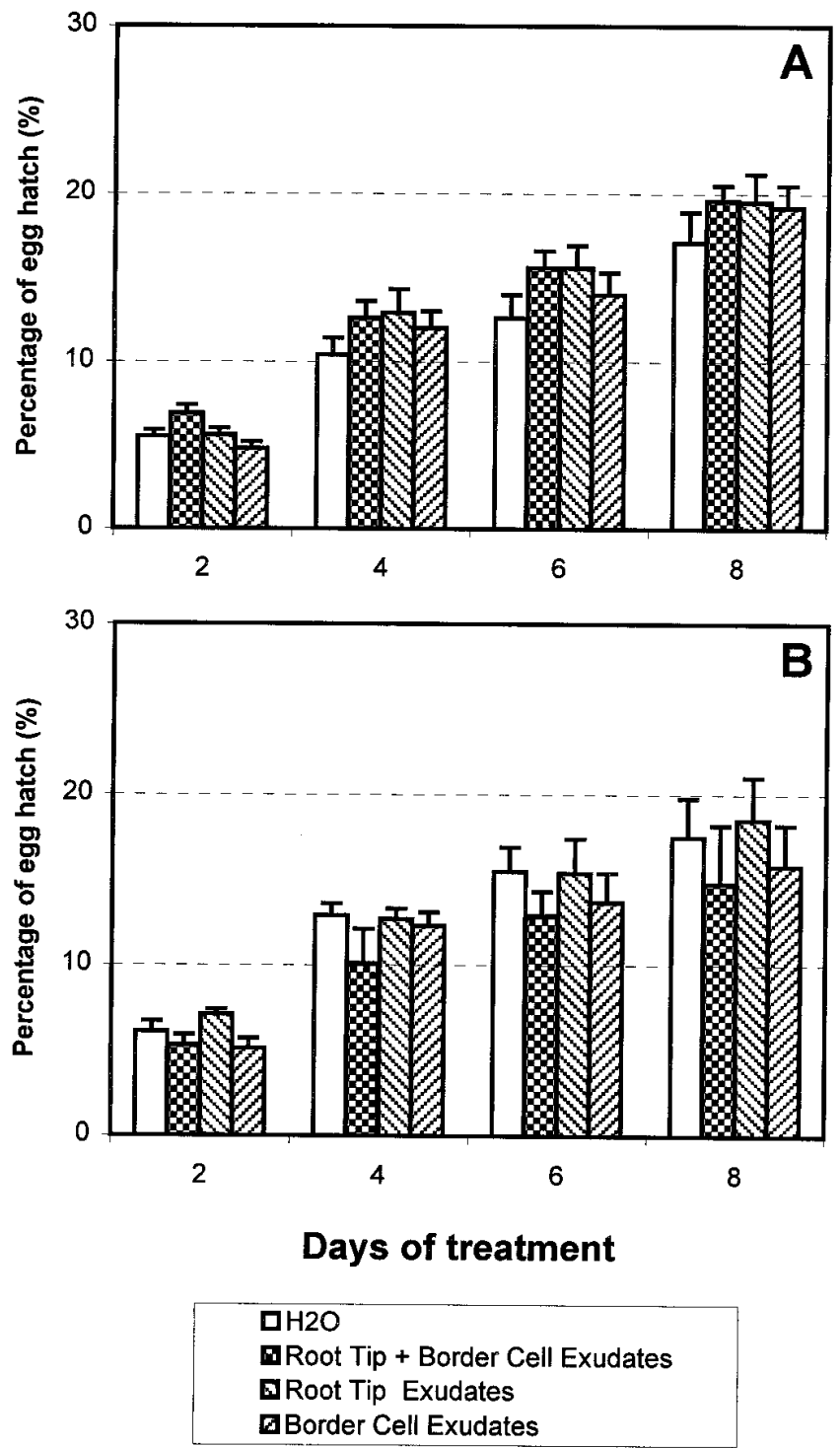

Fig. 1. Effects of root tip and border cell exudates on Meloidogyne incognita egg hatch. A, Pea; B, snap bean. Values represent the means and standard errors of three replicates for each treatment from a total of three independent experiments. standard check cultivars for root knot nematode resistance were also included (13). These cultivars are Moapa 69 (resistant) and Lahontan (susceptible) $(13,28)$.

Pea and corn seeds were surface sterilized in $95 \%$ ethanol for $10 \mathrm{~min}$ followed by $30 \mathrm{~min}$ in full strength commercial bleach $(5.25 \% \mathrm{NaOCl})$. Alfalfa seeds were sterilized for $10 \mathrm{~min}$ in ethanol and $10 \mathrm{~min}$ in bleach. Snap beans were sterilized $3 \mathrm{~min}$ in ethanol and $30 \mathrm{~min}$ in $30 \%$ hydrogen peroxide. Seeds then were rinsed in sterilized distilled water six times, followed by immersion in sterilized distilled water for $6 \mathrm{~h}$ ( $1 \mathrm{~h}$ for alfalfa). The imbibed seeds were germinated at $24^{\circ} \mathrm{C}$ on $1.0 \%$ water agar (SigmaAldrich, St. Louis) overlaid with sterilized germination paper as described previously (20).

Collections of root tip exudates and border cell exudates. Border cells were collected as described previously (20). Root tips of intact seedlings (10 for pea, snap bean, and corn and 30 for alfalfa) were immersed in $1 \mathrm{ml}$ of sterilized distilled water for 1 to $2 \mathrm{~min}$ and border cells and associated exudates were removed by agitating the water gently using a Pasteur pipette. "Root tip exudate" is defined here as all material that can be washed from the tips of roots $25 \mathrm{~mm}$ in length, excluding border cells, after germination of seeds on $1.0 \%$ water agar overlaid with filter paper. Root tip exudate is a cell-free supernatant that is obtained after border cells are pelleted at 7,000 rpm for $10 \mathrm{~min}$. Excluding chemicals that may have diffused into the germination paper or the water agar during the period of germination, root tip exudate includes all material secreted during root emergence by cells of the root tip, as well as all chemicals secreted by border cells and all chemicals from cell walls released as border cells separate from the root tip during emergence (40). The pelleted border cells were washed in sterilized distilled water once to remove residual root tip exudate. The effects of border cell exudate, the diverse array of water soluble extracellular products that are exported by detached border cells (3), were measured using populations of border cells as experimental samples. The final concentration of border cells was adjusted by direct counts to $1 \times 10^{5}$ per milliliter $(\approx 20$ seedlings for pea, snap bean, or corn and 60 seedlings for alfalfa).

Nematodes. Eggs of $M$. incognita race 3 were harvested from roots of infected greenhouse-grown eggplants 6 to 8 weeks after inoculation. To obtain second-stage juveniles (J2), eggs were hatched in distilled water above a 20 -micron nylon fiber screen. J2 below the screen were collected 2 days later.

C. elegans $\mathrm{N} 2$ was used as a nonpathogenic nematode control. $C$. elegans was grown on nematode growth medium (NGM) agar with a lawn of Escherichia coli OP50 as food source (38). C. elegans juveniles were washed with $1.25 \times \mathrm{M} 9$ buffer three times before use in experiments (38).

Effects of root tip exudates and border cell exudates on egg hatch of $\boldsymbol{M}$. incognita. Sterilized tissue culture plates with 24 wells (Greiner Labortechnik, Kaysville, UT) were used for egg hatch experiments. Pea and snap bean were used as test plants. For each experimental manipulation, there were three different treatments (border cells; root tip exudate; border cells + root tip exudate) and a control with water only. Root tip exudate or border cells from 10 seedlings $(\approx 5,000$ border cells per seedling) were combined with 20,000 eggs of $M$. incognita in each well, and the final volume of solution in each well was $2 \mathrm{ml}$. J2 and egg numbers were counted daily for 8 days to calculate the percentage of hatching (number of $\mathrm{J} 2 /$ number of $\mathrm{J} 2+$ eggs) over time. There were three replicate wells for each treatment and the number of eggs and $\mathbf{J} 2$ for each well was the average of three counts (10 $\mu \mathrm{l}$ each). The whole test was carried out twice.

Effects of root tip and border cell exudates on chemotaxis of $\mathbf{J} 2$ from M. incognita. Responses of nematodes to whole roots. J2 suspension $(50 \mu$ l containing $200 \mathrm{~J} 2)$ was spread onto the surface of 60-by-15-mm petri plates (Becton Dickinson, Lincoln Park, NJ) containing $0.7 \%$ agarose (Sigma-Aldrich). The plates were dried at room temperature until no free water was seen on the surface 
and $\mathrm{J} 2$ could be observed microscopically to be moving freely on the surface. Roots of pea or snap bean seedlings ( $25 \mathrm{~mm}$ long), with or without border cells (harvested as described above), were placed onto the surface of the plates containing nematodes. The responses of the nematodes were monitored microscopically over a 2-h period; longer incubation periods were compromised by diffusion of exudates into the agar. Each assay was repeated at least five times.

Chemotactic responses of nematodes to border cell and root tip exudates. Quiz sand (\#20; Home Depot, Tucson, AZ) was separated into three sections within petri dishes $(60$ by $15 \mathrm{~mm}$, Becton Dickinson), using 250-mesh screens (20-micron opening) placed vertically across the center of the dish, with a $1.5-\mathrm{cm}$ middle section and $2-\mathrm{cm}$ wide sections on each side. The water concentration of the sand was set at $10 \%$ (wt/wt) before filling the plates. A sample of border cells or root tip exudate (from 10 seedlings of pea and snap bean or 30 seedlings of alfalfa) was added to one side of the petri dish, and an equal volume of water was added to the other side. A sample of $\mathbf{J} 2$ was added in the middle section. The treatments included water versus border cells, water versus root tip exudate, water versus border cells + root tip exudate, and water on both sides as control. After 3 days, the sand in each side of the dish was removed separately. The $\mathbf{J} 2$ in each section were collected into suspension by washing the sand in $50 \mathrm{ml}$ of water three times. The suspension then was passed through a 500-mesh (10-micron opening) sieve. Residues above the sieve were placed on glass slides and the number of $\mathrm{J} 2$ was counted directly using a light microscope.

The chemotaxis ratio was calculated based on the relative numbers of $\mathrm{J} 2$ present on each side of the plate. Thus, a 1:1 ratio represents a neutral response; a $+4: 1$ ratio represents a positive chemotaxis response, with four times more $\mathrm{J} 2$ present in the side containing exudate or border cells than in the side containing water; and a $-4: 1$ ratio represents a negative chemotaxis response, with four times more $\mathrm{J} 2$ present on the side containing water than the side containing exudate or border cells. Three replicate plates were included for each treatment and the whole test was repeated three times.

Effects of root tip exudates and border cell exudates on motility of nematode juveniles. In preliminary whole-plant assays, nematodes were observed to lose motility after accumulation within clumps of detached border cells, but concerns about diffusion of soluble exudates into the agar precluded long-term assays. Pea, snap bean, alfalfa, and corn were used as test plants to further study the impact of border cell exudates on the motility of juveniles when exposed during hatching or when exposed after hatching. Treatments included border cells, root tip exudates, and border cells + root tip exudates with $\mathrm{H}_{2} \mathrm{O}$ as control. Root tip exudates or border cells from 10 seedlings $/ \mathrm{ml}$ (30 seedlings $/ \mathrm{ml}$ for alfalfa) were placed in individual wells of a sterile 24-well tissue culture plate, with a total volume of $2 \mathrm{ml}$. In all, 20,000 eggs or $4,000 \mathrm{~J} 2$ of $M$. incognita or juveniles of C. elegans were used in each treatment. Triplicate samples containing several hundred eggs or J2 were removed, and the number of motile versus nonmotile nematodes was determined by direct counts using a light microscope. Motility was measured once daily for 4 to 5 days.

The quantitative assay was used to compare the effects of root tip and border cell exudates on $\mathrm{J} 2$ behavior. The same sterilized tissue culture plates with 24 wells were used in this experiment. The concentration of the root tip exudates and border cells were set at 10 seedlings/ml $(1 \times)$ and 5 seedlings/ml $(0.5 \times)$, with $\mathrm{H}_{2} \mathrm{O}$ as a control. The total volume in each well was $2 \mathrm{ml}$, with 4,000 $\mathrm{J} 2$ of $M$. incognita. The numbers of curling, actively motile $\mathrm{J} 2$ and motionless, straight $\mathrm{J} 2$ were counted directly by microscopic observation after an overnight incubation (16 h later). There were three repeats for each treatment in both tests and the tests were carried out twice.

Effects of root tip exudates on secretion by $M$. incognita. Secretion of $\mathrm{J} 2$ can be detected by staining with Brilliant Blue $\mathrm{R}$ (Sigma-Aldrich) (29). A 10- $\mu$ l sample of J2 suspension (con- taining $100 \mathrm{~J} 2$ ) was mixed with $10 \mu \mathrm{l}$ of $0.2 \%$ brilliant blue (in $20 \%$ methanol) and $10 \mu \mathrm{l}$ of $\mathrm{H}_{2} \mathrm{O}$ or root tip exudates on top of a microscope slide. The cover slip was sealed with clear nail polish and slides were incubated at room temperature in the dark overnight. J2 secretions were observed using a light microscope.

Effects of root exudates and nematodes on border cells. Preliminary observations suggested that border cells undergo changes in shape in response to incubation with nematodes. To quantify this phenomenon, experiments were carried out using sterilized tissue culture plates with 24 wells (Greiner Labortechnik, Kaysville, UT). Test plants used were pea and snap bean. In each well, border cells from 10 seedlings (final concentration $\approx 1 \times 10^{5} / \mathrm{ml}$ ) were mixed in $1 \mathrm{ml}$ of water or root exudates, with or without 20,000 eggs of $M$. incognita, 2,000 J2 of $M$. incognita, or 2,000 juveniles of $C$. elegans. The final volume was $1.5 \mathrm{ml}$. Alternatively, border cells were incubated in water containing $0.2 \mathrm{mg}$ of 2,4-dichlorophenoxyacetic acid and $1.0 \mathrm{mg}$ of 1-naphthaleneacetic acid (NAA) per liter (21). The experiment was carried out at $24^{\circ} \mathrm{C}$ in an incubator in the dark overnight. The percentages of border cells which exhibited bulging, swelling, or other shape changes were determined by direct counts, using a light microscope. All experiments were repeated at least three times.

Statistics. All of the tests were repeated at least twice and statistics were performed using an analysis of variance (ANOVA) program of correlation functions of EXCEL (Microsoft Corp., Redmond, WA).

\section{RESULTS}

M. incognita egg hatching does not depend on root exudates. The number of $\mathrm{J} 2$ present increased by $\approx 5 \%$ per day in every treatment, including the $\mathrm{H}_{2} \mathrm{O}$ control (Fig. 1). No significant difference $(P>0.05)$ was detected among treatments when either pea or snap bean were used as the test plant (Fig. 1).
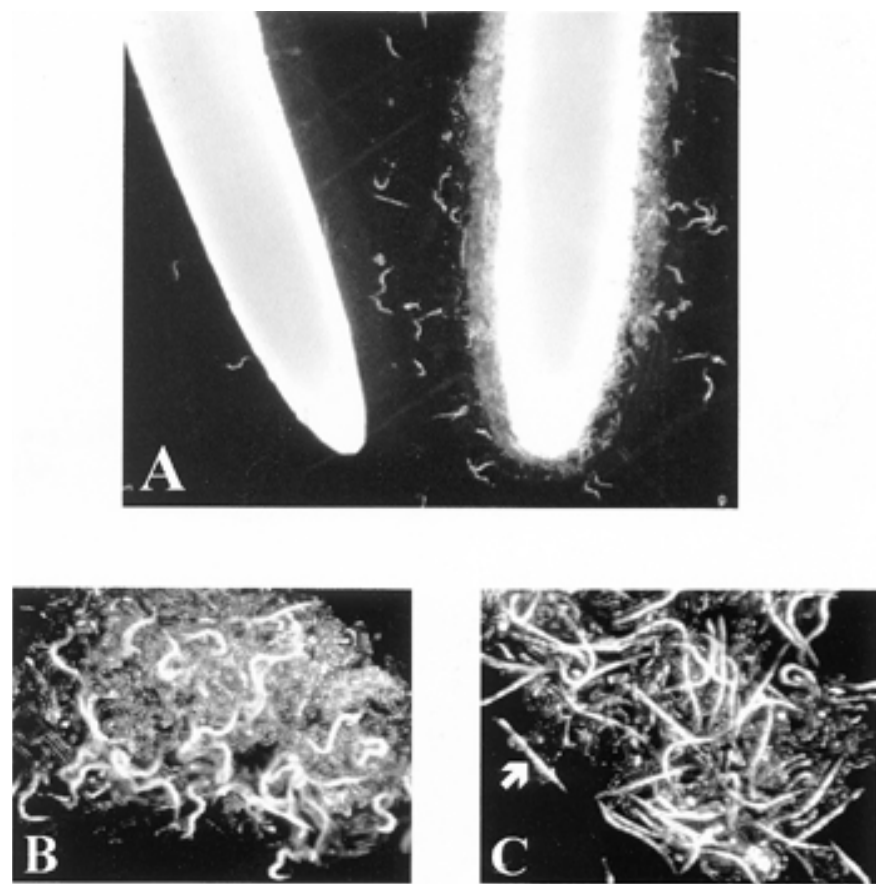

Fig. 2. Localized chemotactic attraction and induced quiescence of Meloidogyne incognita by pea roots. A, When border cells were removed prior to placing a seedling onto a lawn of actively motile second-stage juveniles, no accumulation occurred (left). In contrast, within $5 \mathrm{~min}$, an accumulation of nematodes was apparent at the root tip periphery of roots with border cells present (right). B, When the root with border cells was lifted from the plate, a high concentration of actively motile nematodes were found to be associated with clumps of detached border cells. C, Within $30 \mathrm{~min}$, most of the nematodes within clumps of detached border cells had assumed a rigid, stick-like posture and had ceased movement (arrow). 

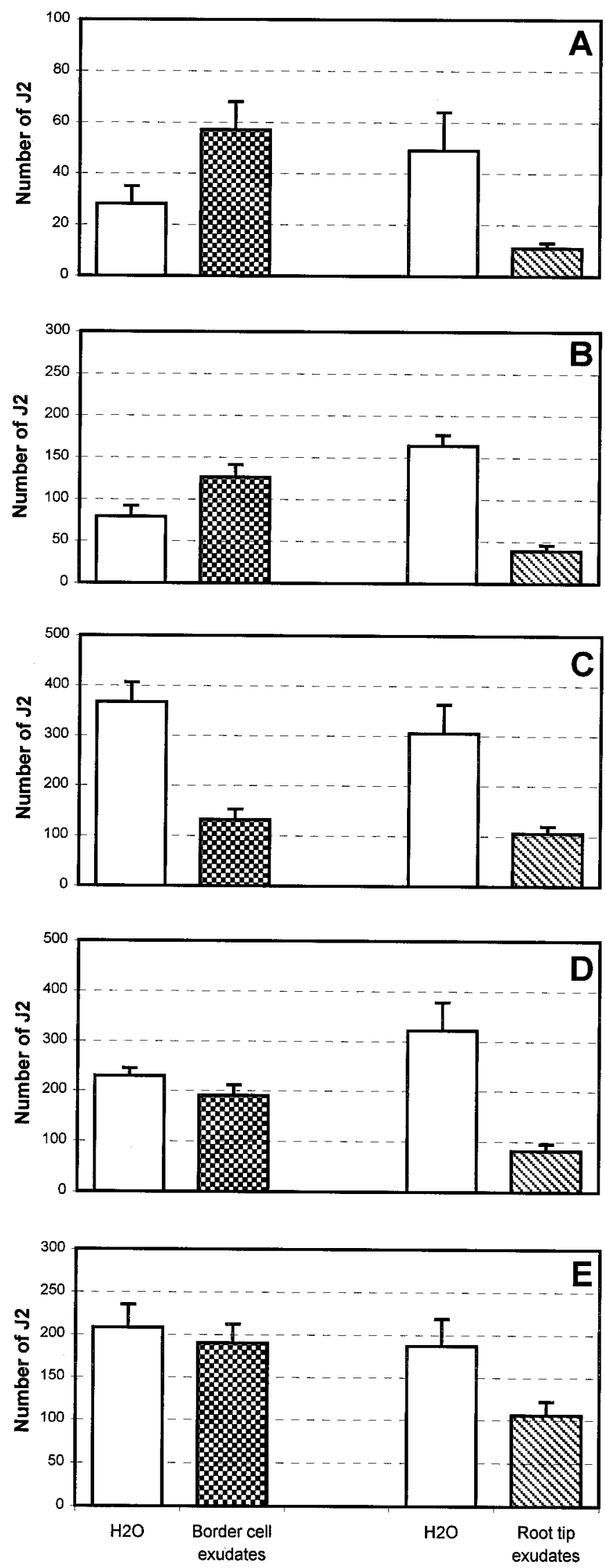

Fig. 3. Differential chemotactic responses of Meloidogyne incognita to root tip and border cell exudates. A, Pea; B, alfalfa cv. Thor; $\mathbf{C}$, alfalfa cv. Moapa 69; D, alfalfa cv. Lahontan; and $\mathbf{E}$, snap bean. Values represent the means and standard errors of three replicates for each treatment from a total of three independent experiments.
Host-dependent chemotaxis of $M$. incognita to root tips of whole plants, and loss of motility within clumps of detached border cells. When whole pea seedlings were placed onto petri plates, nematodes were attracted to the region at the root tip where border cells are present. Within $5 \mathrm{~min}$, a higher concentration of nematodes was visible at this site (Fig. 2A, right). In contrast, when border cells (and their associated root tip exudates) were washed from root tips prior to placing the roots onto the plate, no accumulation of nematodes at the root tip was detectable (Fig. 2A, left). No attraction to the region of elongation was detected.

When root tips with border cells were lifted from the plate, clumps of border cells (with associated root tip exudates) frequently detached and were left on the surface of the plate. A marked accumulation of nematodes within such clumps of pea border cells was evident (Fig. 2B). J2 which accumulated within a clump of border cells and associated root tip exudates initially were actively motile. Continuous motility could be observed microscopically and detected photographically by a sinuous body structure (Fig. 2B). Within $30 \mathrm{~min}$, however, motility of $\mathrm{J} 2$ within border cell clumps ceased, even though worms elsewhere on the plate remained fully active. The loss of motility within clumps of border cells was associated with the assumption of a rigid, sticklike posture that did not fluctuate (Fig. 2C, arrow). The loss of motility of nematodes within border cell clumps was retained for the 2-h duration of the plate assay, even though nematodes elsewhere on the plate exhibited continuous movement. When the same test was duplicated using snap bean seedlings, no such accumulation was observed, nor was there an obvious loss of nematode movement (data not shown). Experiments, described below, were carried out to quantify the chemotaxis and motility phenomena under controlled conditions, and to compare the responses with different cellular sources of exudate as well as with exudate from different plant species.

Host-dependent positive and negative chemotaxis reactions of $M$. incognita to isolated root border cells. When border cells were used as a stimulus in a quantitative chemotaxis assay carried out in sand, positive attraction $(P<0.05)$ of $\mathrm{J} 2$ to pea border cells was observed, with a chemotaxis ratio of 2.0 (Fig. 3A). Nearly identical responses occurred when border cells from alfalfa cv.
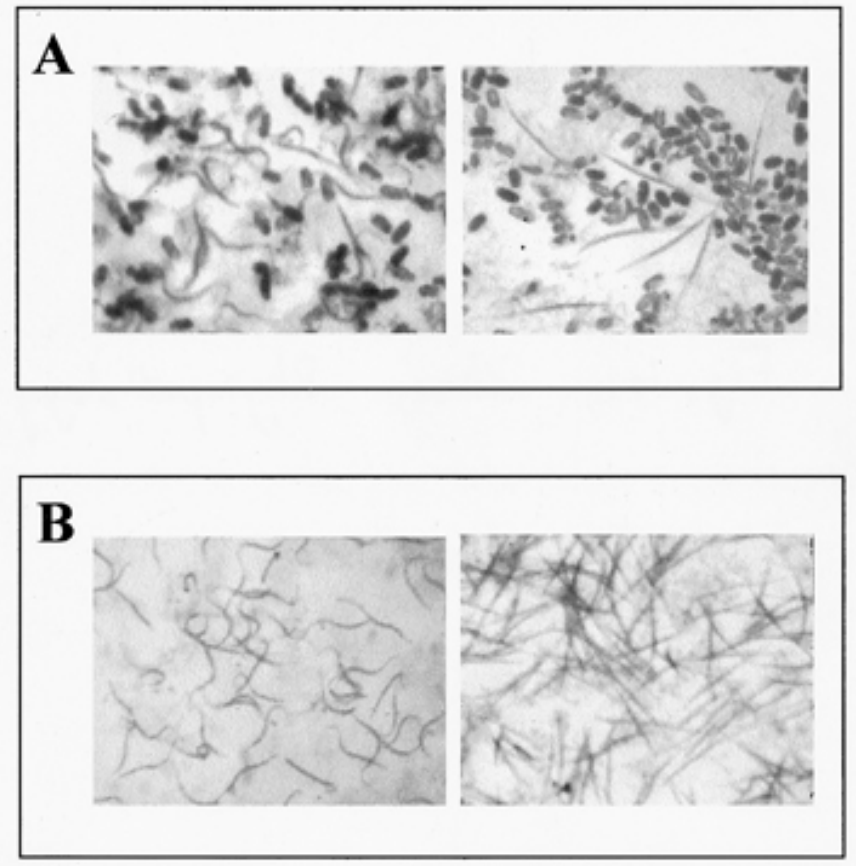

Fig. 4. Induced quiescence of Meloidogyne incognita by root exudates. A, During egg hatching. Left, water control; right, root tip exudates. B, After egg hatch. Left, water control; right, root tip exudates. 
Thor V6086 were used as the attractant $(P<0.05)$, resulting in a chemotaxis ratio of 1.6 (Fig. 3B). In contrast, border cells from alfalfa cv. Moapa 69 repelled J2 populations, with a negative chemotaxis ratio of $-2.8(P<0.05)$ (Fig. 3C). Finally, border cells from alfalfa cv. Lahonton (Fig. 3D) and snap bean (Fig. 3E) elicited no response from the nematodes, with chemotaxis ratios that were not statistically $(P>0.05)$ distinct from control values of 1:1.

Repulsion of nematodes by isolated root tip exudates. To determine if root tip exudates as well as border cell exudates act as an attractant to $\mathrm{J} 2$ of $M$. incognita, the quantitative chemotaxis assay was used. Surprisingly, the root tip exudates of pea, whose border cells attracted $\mathrm{J} 2$, instead were found to repel $\mathrm{J} 2$ populations (Fig. 3A). In contrast to the host-selective chemotaxis responses to border cells, this result occurred irrespective of the plant species or cultivar (Fig. 3B-E), with negative chemotaxis ratios of $\geq 2.0(P<0.05)$ in each case. Repulsion of nematodes by root tip exudates occurred whether or not border cells were removed from the exudate prior to the assay (data not shown).

Induced quiescence of $M$. incognita by root tip exudates. When eggs were hatched in the presence of root tip exudates (Fig. $4 \mathrm{~A}$ ), or when $\mathrm{J} 2$ were incubated with root tip exudates overnight (Fig. 4B), loss of motility occurred as it did in plate assays using pea (Fig. 2C). The phenomenon was examined in more detail using a quantitative assay based on movement in sand.

The results of the quantitative assay used to measure $\mathrm{J} 2$ motility revealed that the active factor, like the chemorepellent, was present in root tip exudates but not border cell exudates. After an overnight incubation, nearly all nematodes incubated in water or in border cells alone were observed to be motile (Fig. 5). In contrast, most nematodes that had been incubated in root tip exudates, with or without border cells, had lost motility $(P<0.05)$. The effect was dosage dependent: a twofold dilution of root tip exudate prior to incubation with $\mathrm{J} 2$ reduced the number of immobilized nematodes by more than half.

The root tip exudate-induced state of quiescence was transient and reversible. Over a 5-day period, J2 populations incubated in water only exhibited continuous motility, whereas $\mathrm{J} 2$ populations incubated in full-strength exudates remained nonmotile and appeared to be dead. However, after 6 days, the $\mathrm{J} 2$ which had been incubated continuously in full-strength root exudates resumed full motility (data not shown). The appearance of the population was indistinguishable from that of controls. This result indicated that, despite the loss of motility, the root exudates were not killing or irreversibly injuring the nematodes. Experiments were carried out to determine if motility could be recovered earlier if nematodes were washed to remove them from exposure to root exudates. When washed and resuspended in water and then examined, the populations were found to resume motility immediately (data not shown).

This reversible, root exudate-induced quiescence occurred in $C$. elegans as well as $M$. incognita and in response to root tip exudates for all varieties tested (data not shown). To determine if the effect was specific to legumes, corn root tip exudates were assayed and found to induce quiescence as effectively as the dicot species (data not shown).

Stimulation of nematode secretion by root exudates. Massive secretion was detected in response to incubation with root tip exudates (Fig. 6B, arrows), but not in water-treated controls (Fig. 6A).

Pea border cell shape changes caused by coincubation with nematodes. Border cells normally exhibit an elongated but uniform shape (Fig. 7A). Incubation of pea border cells with J2 populations resulted in the development of pronounced swelling of the plant cells (Fig. 7B). Similar changes occurred in response to incubation with plant hormones (Fig. 7C). In both treatments, $1.5 \pm 0.3 \%$ of the cells developed changes in shape within $48 \mathrm{~h}$. $M$. incognita has been reported to secrete growth factors which may be a part of their arsenal for inducing giant cell formation $(5,22)$. The changes occurred in response to cocultivation with $M$. incognita eggs or $\mathrm{J} 2$ populations, but not in response to cocultivation with C. elegans, and was influenced by plant species: No shape changes occurred in snap bean border cells incubated with $M$. incognita eggs or $\mathrm{J} 2$ populations (data not shown).

\section{DISCUSSION}

More than 60 years ago, research efforts were undertaken to identify plant exudates that mediate nematode-root recognition and thereby offer potential avenues for crop protection $(1,23)$. Thus, the identification of attractants or repellents associated with resistance or susceptibility might be introduced to crops directly, or through genetic manipulation. In some cases, chemotaxis was correlated with disease (11) but, in other cases, no such correlations were detected. Such discrepancies made it difficult to draw conclusions about a role for nematode-root recognition in resistance or susceptibility (33). Even more confusing was the discovery that exudates from a single plant could result in positive, negative, or neutral chemotaxis responses in a given nematode

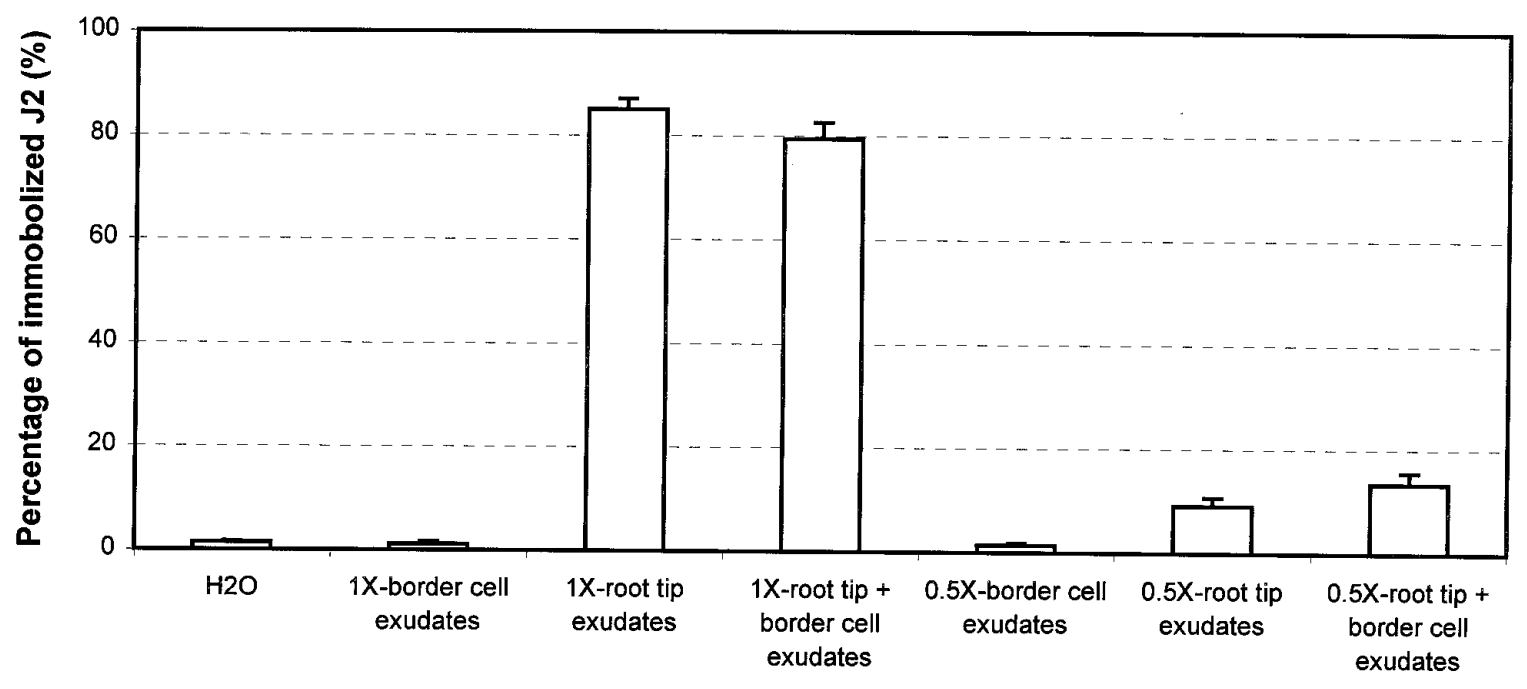

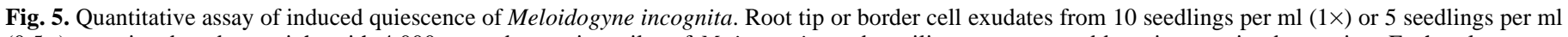

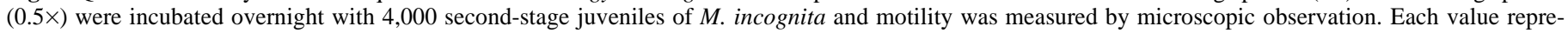
sents the mean of three replicate samples in at least two independent experiments. 
species, depending on the conditions of the assay $(11,12,33,34)$. Investigators concluded that it was the combination of signals in a given set of exudates that determines the behavior in a given plant-nematode interaction (30).

Studies in recent years have validated the premise that exudates of individual plants can contain a mixture of positive and negative effectors of gene expression and behavior in root-associated organisms (9). Such discoveries have focused attention on the "microniche" concept, in which it is the chemical balance within localized sites on the root surface and the rhizosphere that drives population dynamics leading to disease or symbiosis (27). For example, repulsion from cells in one region and attraction to another could contribute to localized infection patterns. The importance of understanding the specific cellular sources of such material, therefore, has been highlighted. In the current study, we measured the impact of legume root exudates on three parameters of nematode behavior during early plant-nematode recognition: egg hatch, chemotaxis, and J2 motility. The impact of total root tip exudates was contrasted with that of exudates released specifically by border cells. As others have reported, exudates caused little or no change in $M$. incognita egg hatch (26). However, the two distinct cellular sources of plant material-root tip and border cell exudates-from a given plant species elicited distinct behavioral responses in two species of nematode, $M$. incognita and $C$. elegans. The results may help to explain contradictory results obtained in past studies and offer new approaches to controlling early stages of root-nematode recognition.

Root border cells and the root cap-exuded mucilage that encases them constitute a major component of root exudates in most agronomically important crop species. Border cells are a source of products that are distinct from those of progenitor cells in the root cap; they constitutively synthesize and export an array of proteins and other chemicals, and also respond to microorganisms and other external stimuli to synthesize products of inducible pathways $(3,15,18,19,39,40)$. In the current study, border cell exudates
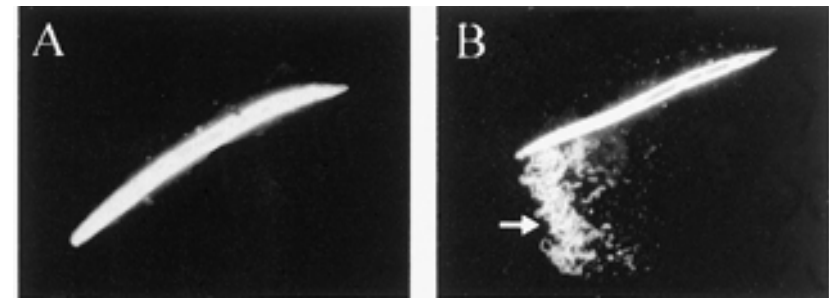

Fig. 6. Effects of pea root tip exudates on secretion by second-stage juveniles (J2) of Meloidogyne incognita. A 10- $\mu 1$ sample of J2 suspension (containing $100 \mathrm{~J} 2$ ) was mixed with $10 \mu \mathrm{l}$ of $0.2 \%$ brilliant blue (in $20 \%$ methanol) and $10 \mu \mathrm{l}$ of $\mathrm{H}_{2} \mathrm{O}$. The cover slip was sealed with clear nail polish and slides were incubated at room temperature for $16 \mathrm{~h}$ and photographed using a light microscope. A, Appearance of nematodes incubated in water and $\mathbf{B}$, appearance of nematodes incubated in root tip exudates. elicited three distinct behavioral responses. Border cells of a resistant cultivar of alfalfa, Moapa 69, repelled nematodes. Border cells of two hosts, pea and alfalfa cv. Thor, were chemotactically attractive, whereas border cells of two other hosts, alfalfa cv. Lahonton and snap bean, elicited no reaction. Root tip exudates, in contrast, were consistent across all of the tested varieties in their ability to repel $\mathbf{J} 2$ populations. This was true despite the fact that attractants in pea and alfalfa border cell exudates released extracellularly during germination are a component of root tip exudates.

In planta assays using intact pea seedlings yielded surprising results that, to our knowledge, have not been documented previously: A rapid attraction of $\mathbf{J} 2$ to the root tip periphery occurred only when border cells were present. When border cells (and associated root tip exudates) were washed from the root prior to the assay, no attraction to the root tip occurred. This is despite the fact that, under such circumstances, the root periphery contained not only border cells which are attractive to $\mathrm{J} 2$, but also root tip exudates whose repellent activity predominates when the material is washed from the root and used in sand assays. Thus, in the plate assay, attraction to border cells on the root tip occurred despite the presence of root tip exudates; whereas, in the sand assay, repulsion occurred despite the presence of attractive border cells. One explanation for this discrepancy could involve differences in solubility of particular components of the mixture under different circumstances. For instance, the root tip chemorepellent, but not the border cell chemoattractant, could bind to agar such that the effective concentration is reduced, whereas no such binding may occur in sand.

An important survival strategy of many organisms is a capacity to assume a quiescent state in response to toxic or otherwise repellent environmental conditions (26). Possibly of most interest in this study was the discovery that juvenile populations of both $C$. elegans and $M$. incognita undergo a comprehensive but transient, reversible change in motility in response to root tip exudates isolated from all genotypes of all of the tested legume species. That the reaction is not specific to legumes was demonstrated by its presence in corn root tip exudates. To our knowledge, this induced quiescence response to root tip exudates has not previously been reported. It is interesting to note that while all four species-corn, pea, alfalfa, and snap bean-are hosts to root knot nematode, the root tips of all the plants nevertheless are effectively "resistant". Even though $M$. incognita $\mathrm{J} 2$ can move into and through the root tip intracellularly once they have penetrated to the root's interior, cellular infection is initiated and maintained not in the root tip but in the region of elongation just behind the tip $(8,28)$. This pattern of tissue specific localization is common to most root-infecting pathogens and symbionts and is probably a plant-driven phenomenon whose adaptive advantage involves protection of the apical meristem (19). The root tip moves at a rate of $\approx 1 \mathrm{~mm} / \mathrm{h}$. Thus, once a root tip reaches a given location in the soil, within several hours it is replaced at that location by a region of elonga-
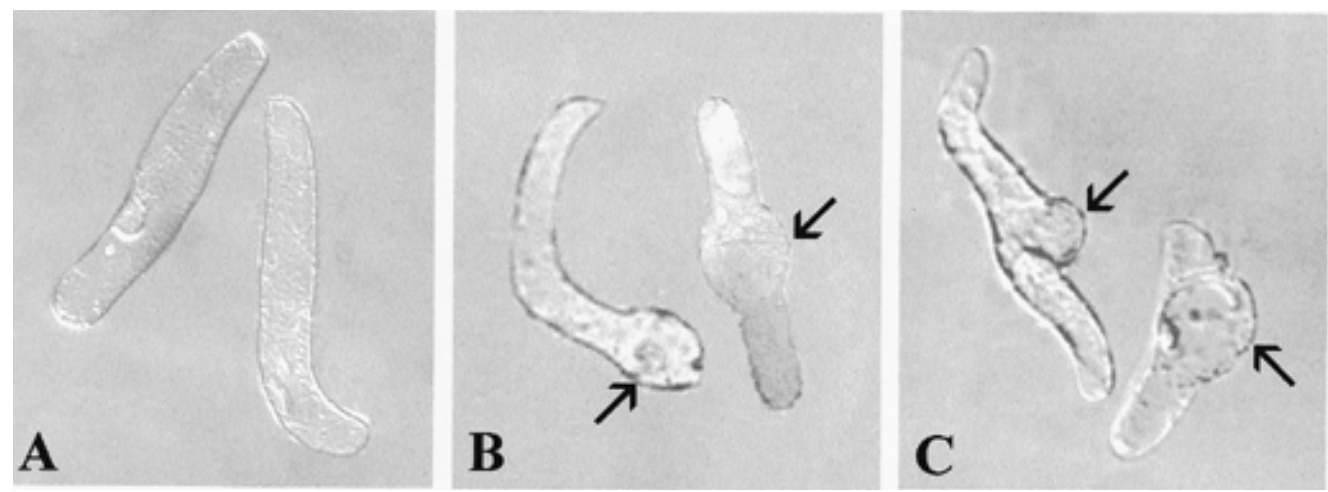

Fig. 7. Effect of nematode exudates on border cells. Appearance of A, control border cells and shape changes (arrows) induced by B, cocultivation with Meloidogyne incognita second-stage juvenile populations or by $\mathbf{C}$, incubation with plant hormones. 
tion. An ability of the root tip to deliver products that temporarily immobilize populations of nematodes encountered in the soil conceivably could play a role in the ability of the root tip to escape infection.

The mechanism or mechanisms by which root tip exudates induce quiescence in $M$. incognita and $C$. elegans is not known. The observation that incubation in root tip exudates induces a marked increase in secretion by $M$. incognita could be directly related to its mode of action, or could be coincidental. Mutants of C. elegans with specific alterations in perception and response pathways can be used to evaluate how the factor in root tip exudates controls nematode motility. The use of genetic engineering to deliver such products to regions where infection is initiated would be a potential new avenue to control nematodes with less threat to the environment than synthetic chemicals.

\section{ACKNOWLEDGMENTS}

This work was supported by grants from the United States Department of Agriculture. We thank M. A. McClure for advice, materials, and other assistance with all aspects of this work.

\section{LITERATURE CITED}

1. Bird, A. F. 1959. The attractiveness of roots to the plant parasitic nematodes Meloidogyne javanica and M. hapla. Nematologica 4:322-335.

2. Bird, A. F. 1974. Plant response to root-knot nematode. Annu. Rev. Phytopathol. 22:69-85.

3. Brigham, L. A., Woo, H. H., and Hawes, M. C. 1995. Differential expression of proteins and mRNAs from border cells and root tips of pea. Plant Physiol. 109:457-463.

4. Brigham, L. A., Woo H. H., Wen, F., and Hawes M. C. 1998. Meristemspecific suppression of mitosis and a global switch in gene expression in the root cap of pea by endogenous signals. Plant Physiol. 118:1223-1231.

5. Cohn, E., Koltai, H., Sharon, E., and Spiegel, Y. 1996. Root-nematode interactions: Recognition and pathogenicity. Pages 783-796 in: Plant Roots: The Hidden Half. 2nd ed., revised and expanded. Y. Waisel, A. Eshel, and U. Kafkafi, eds. Marcel Dekker Inc., New York.

6. Cooperative Extension Service, University of Illinois and Extension Service, United States Department of Agriculture. 1977. A Compendium of Corn Disease. St. Paul, MN.

7. Curl, E. A., and Truelove, B. 1986. The Rhizosphere. Springer-Verlag, Berlin.

8. deAlmeida Engler, J., de Vleesschauwer, V., Burssens, S., Celenza, J. L. Jr., Inzé, D., van Montage, M., Engler, G., and Gheysen, G. 1999. Molecular markers and cell cycle inhibitors show the importance of cell cycle progression in nematode induced galls and syncytia. Plant Cell 11:793-807.

9. Djordjevic, M. A., Redmond, J. W., Batley, M., and Rolfe, B. G. 1987. Cloves secrete specific phenolic compounds which either stimulate or repress nod gene expression in Rhizobium trifolii. EMBO J. 6:1173-1179.

10. Griffin, D. M., Hale, M. G., and Shay, F. 1976. Nature and quantity of sloughed organic matter produced by roots of axenic peanut plants. Soil Biol. Biochem. 8:29-32.

11. Griffin, G. D. 1969. Attractiveness of resistant and susceptible alfalfa to stem and root-knot nematodes. J. Nematol. 1:9.

12. Griffin, G. D., and Elgin, J. H. J. R. 1977. Penetration and development of Meloidogyne hapla in resistant and susceptible alfalfa under differing temperatures. J. Nematol. 9:51-56.

13. Griffin, G. D., Peaden, R. N., and Knipe, W. J. 1991. Root-knot nematode resistance. Page N-2 in : Standard Tests to Characterize Alfalfa Cultivars. U. S. Dep. Agric. U.S. Gov. Print. Office, Washington, D.C.

14. Hagedorn, D. J. 1989. Pages 38-40 in: Compendium of Pea Disease. The American Phytopathological Society, St. Paul, MN.

15. Hawes, M. C. 1990. Sloughed root cap cells: A regulator of microbial populations in the rhizosphere? Plant Soil 129:19-27.

16. Hawes, M. C., and Brigham, L. A. 1992. Impact of root border cells on microbial populations in the rhizosphere. Adv. Plant Pathol. 8:119-148.

17. Hawes, M. C., Brigham, L. A., Nicoll, S. M., and Stephenson, M. B. 1994 Plant genes controlling the release of root exudates. Pages 61-69 in: Biotechnology and Plant Protection-Bacterial Pathogenesis and Disease Resistance. D. D. Bills and S. Kung, eds. World Scientific Publishing Co. Pte. Ltd. Singapore.

18. Hawes, M. C., Brigham, L. A., Wen, F., Woo, H. H., and Zhu, Y. 1998. Function of root border cells in plant health: Pioneers in the rhizosphere. Annu. Rev. Phytopathol. 36:311-327.

19. Hawes, M. C., Gunatilaka, U., Miyasaka, S., and Zhao, X. 2000. The role of root border cells in plant defense. Trends Plant Sci. 5:128-133.

20. Hawes, M. C., and Lin, H. J. 1990. Correlation of pectolytic enzyme activity with the programmed release of cells from root caps of pea (Pisum sativum). Plant Physiol. 94:1855-1859.

21. Hawes, M. C., and Pueppke, S. G. 1986. Isolated peripheral root cap cells: Yield from different plants, and callus formation from single cells. Am. J. Bot. 73:1466-1473.

22. Hussey, R. S. 1989. Disease-inducing secretions of plant-parasitic nematodes. Annu. Rev. Phytopathol. 27:123-141.

23. Linford, B. M. 1939. Attractiveness of roots and excised shoot tissues to certain nematodes. Proc. Helmintiol. Soc. Wash. 6:11-18.

24. Lownsbery, B. F., and Viglierchio, D. R. 1961. Importance of response of Meloidogyne hapla to an agent from germinating tomato seeds. Phytopathology 52:219-221.

25. Lynch, J. M., and Whipps, J. M. 1991. Substrate role in the rhizosphere. Pages 15-24 in: The Rhizosphere and Plant Growth. D. L. Keister and P. B. Cregan, eds, Kluwer Academic Publishers, Boston, MA.

26. Perry, R. N. 1997. Plant signals in nematode hatching and attraction. Pages 38-50 in: Cellular and Molecular Aspects of Plant-Nematode Interaction. C. Fenoll, ed. Kluwer Academic Publishers, Boston, MA.

27. Pierson, L. S. 2000. Expanding the club: engineering plants to talk to bacteria. Trends Plant Sci. 5:89-91.

28. Potenza, C. L., Thomas, S. H., Higgins, E. A., and Sengupta-Gopalan, C. 1996. Early root response to Meloidogyne incognita in resistant and susceptible alfalfa cultivars. J. Nematol. 28:475-484.

29. Premachandran, D., von Mende, N., Hussey, R. S., and McClure, M. A. 1988. A method for staining nematode secretions and structures. J. Nematol. 20:70-78.

30. Prot, J. C. 1980. Migration of plant-parasitic nematodes towards plant roots. Revue. Nematol. 3:305-318.

31. Sasser, J. N., and Freckman, D. W. 1987. A world perspective on nematology: the role of the society. In: Vistas on Nematology. J. A. Veeck, D. W. Dickson, and M. D. Hyattsville, eds. Society of Nematologists, Orlando.

32. Smant, G., Goverse, A., and Stokkermans, J. P. W. G., and de Boer, J. M. 1997. Potato root diffusate-induced secretion of soluble, basic proteins originating from the subventral esophageal glands of potato cyst nematodes. Phytopathology 87:839-845.

33. Viglierchio, D. R. 1961. Attraction of parasitic nematodes by plant root emanations. Phytopathology 51:136-142.

34. Weiser, G. C., Mueller, J. D., and Shipe, E. R. 1987. Response of tolerant and susceptible soybean cultivars to Columbia lance nematode. Soybean Genet. Newsl. U.S. Pep. Agric. Agric. Res. Serv. 14:260-262.

35. Wen, F., Zhu, Y., and Hawes, M. C. 1999. Effect of pectin methylesterase gene expression on pea root development. Plant Cell 11:1129-1140.

36. Williamson, V. M. 1999. Plant nematode resistance genes. Curr. Opin. Plant Biol. 2:327-331.

37. Woo, H. H., Orbach, M. J., Hirsch, A. M., and Hawes, M. C. 1999 Meristem localized inducible expression of an UDP-glycosyltransferase gene is essential for growth and development in pea and alfalfa. Plant Cell 11:2303-2315.

38. Wood, W. B. 1988. Introduction to C. elegans Biology. Pages 1-15 in: The Nematode Caenorhabditis Elegans. W. B. Wood, and the Community of C. elegans Researchers, eds. Cold Spring Harbor Laboratory, Cold Spring Harbor, NY.

39. Zhao, X., Misaghi, I. J., and Hawes M. C. 2000. Stimulation of border cell production in response to increased carbon dioxide levels. Plant Physiol. 122:181-188.

40. Zhu, Y., Pierson III, L. S., and Hawes, M. C. 1997. Induction of microbial genes for pathogenesis and symbiosis by chemicals from root border cells. Plant Physiol. 115:1691-1698. 